\title{
Single Cell Protein Production from Aspergillus Terreus and Its Evaluation in Broiler Chick
}

\author{
Shahzad. M. A and M. I. Rajoka
}

\begin{abstract}
The objective of the study was to produce single cell protein usually termed as microbial biomass using rice as substrate through fermentation with Aspergillus terreus and its biological evaluation in broiler chicks to examine its potential as a suitable poultry feed. Chemical and biological potential of the biomass was evaluated through chemical analysis and chick assay, respectively. After optimizing various conditions such as, substrate: water ratio, nitrogen source, carbon: nitrogen ratio, pH and incubation period. After optimizing fermentation conditions, Aspergillus terreus was grown on broken rice for maximum microbial biomass protein production. Regarding growth kinetics, the specific growth rate $(\mu)$ of the $A$. terreus remained 0.451h-1. The Product coefficients (Yx/s), (Yp/s), $(\mathrm{Yp} / \mathrm{x})$ for the fermentative organism were found $0.553 \mathrm{~g} \mathrm{cell} / \mathrm{g}$ substrate utilized, $0.344 \mathrm{~g}$ protein / $\mathrm{g}$ substrate utilized and $0.622 \mathrm{~g}$ protein / g cell mass formation, respectively. Chemical evaluation of biomass indicated crude protein $43.7 \%$, true protein $26.60 \%$, crude fiber $11.35 \%$ with calorific value as 2730 Kcal. Its ash content was $15.20 \%$ with $1.01 \%$ calcium, $3.05 \%$ phosphorus, $0.64 \%$ sodium and $0.98 \%$ chloride. For biological evaluation, biomass was replaced with soybean meal as 30 ad $60 \%$ on the basis of protein supply and the birds response in terms of weight gain, feed consumption, feed efficiency, feed conversion ratio, protein efficiency ratio and net protein utilization was taken into account. Outcome of the study revealed that microbial biomass produced by $A$. terreus can be replaced upto $30 \%$ of the protein supply by soybean meal without any deleterious effects on growing broiler chicks.
\end{abstract}

Index Terms - Chemical and Biological Evaluation, Growing Broilers, Microbial Protein.

\section{INTRODUCTION}

World population is increasing rapidly while the same response is lacking for human and animal food resources. The number of humans in the world now totals 5.7 billion, is increasing by approximately 94 million annually and will exceed 10 billion by 2050 if left uncontrolled [1]. Population growth, income growth and urbanization are fueling a massive increase in demand for food of animal origin (milk, meat, eggs) in developing countries. The requirement of animal protein for a standard human diet is 30 grams per head per day, but at present the availability of animal protein in Pakistan is 20.2 grams, indicating a shortage of about $33 \%$

Manuscript received June 24, 2011; revised July 13, 2011.

Dr. Muhammad Aasif Shahzad is working as Assistant Professor at the Institute of Animal Nutrition and Feed Technology, University of Agriculture, Faisalabad-38040, Pakistan. (*Corresponding author; phone: +92 321 6642404; fax: +92 419200137 E-mail: draasifshah@uaf.edu.pk).

Muhammad Ibrahim Rajoka is a renowned scientist (Biotechnologist) and currently working as Professor at the Department of Bio-informatics, Government College University, Faisalabad-38040, Pakistan.
[1]. Poultry sector has considerable share in providing animal protein to ever growing human population. However, productivity and profitability by this sector can be enhanced by addressing the issues being faced by this enterprise. Poor quality and high cost of feed ingredients particularly that of protein sources, are considered main threats to its proliferation.

In biotechnology, industrial wastes and byproducts are fermented with various kinds of microbes like bacteria, fungi and yeast and these microorganisms synthesize valuable products such as protein, enzymes, free amino acids, vitamins and many other useful products. On one side this microbial protein will help to fulfill the protein deficiency gap while on the other hand it will also try to meet the threat of shortage of quality ingredients both of vegetable and animal origin. A number of studies have been conducted to improve the nutritional quality of low quality feed stuffs through these microbes for animals. Single cell protein production is a special interest for human societies that have plentiful supplies of cheap carbohydrates and severe shortage of vitamin and protein rich food. A number of studies have been conducted to improve the nutritional quality of low quality feed stuffs. By using these techniques protein content increased upto 37 percent by using rice polishing as a substrate with Arachniotus sp. and Brevibacterium flavum. It has been observed that protein contents may improve upto 4 to 5 folds. Thus ultimate helping to improve the production of animal products like meat milk and eggs. Characteristics of microbes used for single cell protein includes low nutritional requirements, ability to convert complex waste substrate into valuable product, rapid growth rate, stability during multiplication, non-pathogenic, good tolerance to $\mathrm{pH}$ and temperature, low nucleic acid content, capacity of genetic modification, non-toxic and good digestibility.

This necessitates diverting efforts towards exploring new feed resources or improving utilization of available feedstuffs. In this context, biotechnology offers possibilities like production of microbial protein as poultry protein feed. The often quoted comparison that a $0.5 t$ bullock synthesizes less than $0.5 \mathrm{Kg}$ of protein in every 24 -hours, but $0.5 \mathrm{t}$ of soybeans produces the equivalent of $40 \mathrm{Kg}$ protein in every 24-hours and $0.5 \mathrm{t}$ of yeast generates $50 \mathrm{t}$ in this time, illustrates well the main advantage of microbial protein [2]. Keeping in view the current situation the present study was planned to produce microbial biomass from Aspergillus terreus with the objectives to determine the potential of broken rice waste as a substrate for the production of biomass protein, nutritional value of biomass by chemical analysis and its suitability as poultry feed. 


\section{MATERIALS AND METHODS}

\section{A. Biomass Production}

Organism: Aspergillus terreus, The microbial culture was maintained on agar slant media [3]. Inoculum was prepared by transferring aseptically the spores on the agar slant to an autoclaved $250 \mathrm{ml}$ (Erlenmeyer) flask containing $50 \mathrm{ml}$ inoculum medium. The organism (Aspergillus terreus) received after certification from National Institute for Biotechnology and Genetic Engineering (NIBGE), Faisalabad, Pakistan.

Substrate: Broken rice (rice tips) was used a s substrate. It contained dry matter $(92.57 \%)$, moisture $(7.42 \%)$, crude protein $(7.65 \%)$, crude fiber $(1.25 \%)$, ash $(1.20 \%)$, ether extract $(1.75 \%)$, nitrogen free extract $(88.42 \%)$, cellulose $(0.74 \%)$ and caloric value $(2788 \mathrm{Kcal} / \mathrm{Kg})$.

Batch culture cultivation: The Erlenmeyer flask $(250 \mathrm{ml})$ containing $50 \mathrm{ml}$ growth medium plugged with cotton and covered with aluminum foil was autoclaved for 15 minutes at $15 \mathrm{lb} / \mathrm{in}^{2}$. The $\mathrm{pH}$ of medium was adjusted at 6.0 with sterilized $1 \mathrm{~N} \mathrm{HCl}$. A loop full of fungal spores of Aspergillus terreus was added to each flask. The flask was then incubated for three days (72-hours) on orbital shaker working at the rate of $100-120 \mathrm{rpm}$ at $35^{\circ} \mathrm{C}$ temperature. Dulpicate flasks were harvested after 3 days of incubation. Flasks were centrifuged. Intra-cellular protein and enzymes (amylase \& glucoamylase) were determined in the broth (supernatant) of cell mass after centrifugation. Duplicate flasks were harvested after three days incubation. The liquid protein was separated by centrifugation. The protein content and cell mass was measured.

Cell mass determination: The cell mass was determined gravimetrically. The sample was harvested after three days of incubation from separate flasks. The whole sample was centrigugated at 10,000 rpm for 20 minutes The supernatant was separated and the pellet was washed with saline and resuspended and dried in a pre-weighed dry crucible at $100^{\circ} \mathrm{C}$ to a constant mass in duplicate .For insoluble substrate like broken rice the whole $50 \mathrm{ml}$ sample was squeezed from a fine cloth, to get a pellet from which biomass was carefully separated, suspended in saline and dried in an oven using crucible.

Protein determination: The biomass protein was determined by Bradford method using bovine serum albumen as standard

Materials

Bradford reagent

Assay reagent was made by dissolving $100 \mathrm{mg}$ of coomassi blue G250 in $50 \mathrm{ml}$ of $95 \%$ ethanol. The solution was then mixed with $100 \mathrm{ml}$ of $85 \%$ phosphoric acid and made upto 1 liter with distilled water. The reagent was filtered through watman number 1 filter paper before storage in an amber bottle at room temperature .It is stable for several weeks, but slow precipetation of the dye will occur so filtration of the stored reagent is necessary before using.

Protein standard: Bovine serum albumen at a concentration of $1 \mathrm{mg} / \mathrm{ml}$ in distilled water was used as a stock solution. It was stored frozen.

Quartz(silica) Spectrophotometer cuvettes were not used, since the dye binds to this material.Traces of dye bounds to glass or plastic ware were removed with ethanol and detergent solution.

Method: The whole flask was centrifuged after three days of incubation. The supernated was discarded and the cell pellet was suspended in $10 \mathrm{ml}$ of normal saline .Out of this I $\mathrm{ml}$ was taken in a test tube and $1 \mathrm{ml}$ of $1 \mathrm{~N} \mathrm{NaOH}$ was added and allowed to boil for $5 \mathrm{~min}$, again centrifuged and supernatant was subjected to protein determination. Pipeted at a concentration of 200 to 800 micro grams in 200 microgram total volume in test tube in duplicate. In case, the proximate sample concentration was unknown, a range of dilution normally $1,1 / 10,1 / 100,1 / 1000$ were assayed. For the calibration curve duplicate volumes of 200, 300, 400 , $500,600,700$, and 800 micro gram prepared from $1 \mathrm{mg} / \mathrm{ml}$ bovine serum albumen stock were employed $200 \mathrm{ml}$ solution of each was pipeted into test tubes and $2.5 \mathrm{ml}$ of Bradford reagent was added, stirred and allow to stay at room temperature for $10 \mathrm{~min}$, (the reading within $30 \mathrm{~min}$ after adding the reagent).A tube containing 2001 of distilled water was used as a reagent blank. A volume of $2.5 \mathrm{ml}$ of protein reagent was added to each tube and was mixed well by inversion or gentle vortexing taking care to avoid foaming which leads to poor reproducibility. The absorbance of the samples and standard was measured at $595 \mathrm{~nm}$ against the reagent blank after at least 2 minutes and within one hour of mixing. The calibration curve was plotted for each set of assays.

Optimum Conditions: The conditions like substrate: water ratio, nitrogen source, carbon: nitrogen ratio, $\mathrm{pH}$ and incubation period were optimized.

Substrate : water ratio

To optimized substrate:water ratio different levels of broken rice viz. 2, 4, 6, 8 and 10 percent were used, for maximum biomass protein production. Duplicate flasks $(250 \mathrm{ml})$ containing $50 \mathrm{ml}$ of growth medium were incubated on orbital shaker at $\mathrm{pH}$ of 6.0 and at $35^{\circ} \mathrm{C}$ temperature for three days ( 72 hours). The crude protein biomass content thus produced was estimated after 72 hours of incubation. Enzymes (amylase \& glucoamylase) activity was also measured.

Nitrogen source

In order to know a better nitrogen source for maximum microbial protein, various nitrogen sources like, ammonium nitrate,ammonium sulphate, Ammonium di-hydrogen phosphate, fish meal, urea and corn steep liquor were used as nitrogen source. After determining microbial protein after 72 hours, it was observed that corn steep liquor was the best source among these nitrogen sources. Various levels of corn steep liquor were used to know the best nitrogen ( $\mathrm{C}: \mathrm{N}$ ratio) level for maximum microbial protein production.

Carbon: nitrogen ratio

To optimize $\mathrm{C}: \mathrm{N}$ ratio, different $\mathrm{C}: \mathrm{N}$ ratio $(9.6: 1,4.8: 1$, $3.2: 1,2.4: 1,1.92: 1$ and $1.60: 1)$ were used to know the optimum ratio for biomass protein production .It was observed that maximum biomass protein was produced with $4.8: 1$. Hence this ratio was maintained in the subsequent study of condition optimizations. $\mathrm{pH}$

Based on the results of the above experiment another experiment was conducted in order to optimize another condition that is, optimum $\mathrm{pH}$ for biomass production. For this purpose, 3.5, 4.0, 4.5, 5.0 5.5, 6.0, 6.5, 7.0 and 7.5 $\mathrm{pH}$ 
were provided for the growth of microbial biomass.

Incubation period

Incubation period is one of the vital factors for economical biomass production; an experiment was conducted to determine microbial biomass production after 8, 16, 24, 48, 72 and 96 hours of incubation. Hence this was maintained in the subsequent studies.

Large Scale Production of Biomass: Large scale fermentation was carried out in twenty liter capacity glass fermentor.

Assay for alpha-amylase activity: One unit of alpha-amylase activity in each case was defined as amount of enzyme required to liberate one $\mu \mathrm{mol}$ of reducing sugars $/ \mathrm{min} / \mathrm{ml}$. Alpha-amylase assay was performed by some modifications of DNS method.

Growth kinetics: Growth kinetics of Aspergillus terreus, yield of products and specific substrate uptake rate during the fermentation were also calculated by using the following formulas.

$\begin{aligned} \mu & =\frac{1-\mathrm{h} 2 \log \mathrm{h} 1-\mathrm{X} 2 \frac{\mathrm{Xm}}{\mathrm{X} 1}}{\mathrm{Yx} / \mathrm{s} 1-\mathrm{S} 2} \\ \mathrm{Yp} / \mathrm{s} & =\frac{\mathrm{Pm}}{\mathrm{S} 1-\overline{\mathrm{S} 2}} \\ \mathrm{Yp} / \mathrm{x} & =\frac{\mathrm{Pm}}{\mathrm{Xm}}\end{aligned}$

$\begin{aligned} \mathrm{Y} \mathrm{GAM} / \mathrm{S} & =\frac{\mathrm{GAMm}}{\mathrm{S} 1-\mathrm{S} 2} \\ \mathrm{Y} \mathrm{GAM} / \mathrm{x} & =\frac{\mathrm{GAMm}-}{\mathrm{Xm}}\end{aligned}$

\begin{tabular}{|c|c|c|}
\hline AMY/S & $=$ & $\frac{\text { AMYm }}{\mathrm{S} 1-\mathrm{S} 2}$ \\
\hline $\mathrm{Y} \mathrm{AMY/x}$ & $=$ & $\underset{\mathrm{Xm}}{\mathrm{GAMm}}$ \\
\hline$q p$ & $=$ & $\mu \mathrm{X} Y \mathrm{p} / \mathrm{x}$ \\
\hline q GAM & $=$ & $\mu \mathrm{X} \quad \mathrm{YGAM} / \mathrm{x}$ \\
\hline q Amy & $=$ & $\mu \mathrm{X} \mathrm{YAMY} / \mathrm{x}$ \\
\hline
\end{tabular}

where ,

$\begin{array}{lll}\mathrm{X} 1 & = & \text { Initial product } \\ \mathrm{X} 2 & = & \text { Final product } \\ \mathrm{Logn} & = & \text { Log natural } \\ \mu & = & \text { Specific growth rate } \\ \mathrm{Yx} / \mathrm{s} & = & \begin{array}{l}\text { Grams of microbial cells produced } / \text { gram } \\ \text { substrate utilized }\end{array} \\ \mathrm{Yp} / \mathrm{s} & = & \begin{array}{c}\text { Grams of protein formed } / \text { grams of } \\ \text { splestrate utilized }\end{array} \\ & = & \begin{array}{c}\text { Grams of protein formed } / \text { grams of cell } \\ \text { formed }\end{array}\end{array}$

$\mathrm{Y} \mathrm{GAM} / \mathrm{S}=\quad$ Units of Glucoamylase produced / gram substrate utilized

$\mathrm{Y} \mathrm{GAM} / \mathrm{x}=$ Units of Glucoamylase produced / grams cell mass formed

$\mathrm{Y} \mathrm{AMY} / \mathrm{S}=$ Units of Amylase produced / grams substrate utilized

$\mathrm{Y} \mathrm{AMY} / \mathrm{x}=$ Units of Amylase produced / grams cell mass formed

$\mathrm{q} \mathrm{p}=$ Gram protein / gram cells / hour.

q GAM = Units of Glucoamylase /gram cells / hour.

q Amy $\quad=\quad$ Units of Amylase /gram cells /hour

\section{B. Biological Evaluation}

Day-old-broiler chicks (Hubbard) were procured from local market and raised on maize for ten days. Then twenty birds were selected on weight uniformity basis and were randomly allotted to rations, A, B, C and D in such a way that each ration was fed to five birds. Each chick was kept in a separate pen considering it as a replicate. The chicks were individually wing banded for identification. The initial body weight of the experimental birds ranged between 190 to 200 gms. For biological evaluation the biomass was fed to ten days old broiler chicks for a period of ten days. To determine protein quality of biomass, it was replaced with soybean meal with the proportion of $30 \%$ and $60 \%$ respectively.

Composition of experimental rations: Four experimental rations viz; A, B, C and D were prepared. A control ration containing 23.0 percent crude protein and $3200 \mathrm{Kcal}$ metabolizable energy $\mathrm{Kcal} / \mathrm{Kg}$ was prepared and designated as ration " $\mathrm{A}$ ". Rations $\mathrm{B}$ and $\mathrm{C}$ were formulated containing 23 percent crude protein and $3200 \mathrm{Kcal}$ metabolizable energy $/ \mathrm{Kg}$.In ration $\mathrm{B}, 30$ percent of the soybean meal was replaced with biomass protein while in ration $C, 60$ percent of the soybean protein was replaced with biomass. A nitrogen free ration (D) was formulated having $3200 \mathrm{Kcal}$ metabolizable energy $/ \mathrm{Kg}$.

Experimental birds and data collection: Day-old-broiler chicks (Hubbard) were procured from local market and raised on maize for ten days. Then $t$ wenty birds were selected on weight uniformity basis and were randomly allotted to rations, A, B, C and D in such a way that each ration was fed to five birds. Each chick was kept in a separate pen considering it as a replicate. Initial body weight, feed offered \& refused, bird weight were taken into account to study feed conversation ratio, net protein utilization and protein efficiency ratio.

\section{Statistical analysis}

The experiment data were subjected to statistical analysis using Completely Randomized Design .For this purpose the mean values of each treatment replicate were calculated. These replicate means were then used for statistical analysis on the computer and analysis of variance table were prepared for each experiment. Finally the treatment means were computed by Duncan's Multiple Range Test [4].

\section{RESUlTS AND DISCUSSION}

Optimum conditions for microbial biomass 


\section{Substrate-water ratio}

Protein contents obtained on different substrate levels revealed that biomass protein and cell mass was maximum at $2 \%$ substrate to water ratio and biomass true protein and cell mass production was decreased with the increase in substrate: water ratio beyond $2 \%$. Similar findings have been reported by Saima [5] who reported decrease in biomass protein concentration with fermented wheat bran using Candida utilis as a fermentative organism, when used beyond $6 \%$.

\section{Nitrogen source}

In order to know the suitable carbon source for the maximum production of biomass protein , various nitrogen sources viz., ammonium nitrate, ammonium sulphate, ammonium di-hydrogen phosphate, fish meal, urea and corn steep liquor were used in the growth medium @ $1.2 \mathrm{~g} \mathrm{~N} / \mathrm{L}$. The results revealed that maximum biomass protein $(5.09 \mathrm{~g} / \mathrm{L})$ was produced when corn steep liquor was used as a nitrogen source. The possible reason may be that CSL might have some additional growth factors (some amino acids, NFE, minerals, trace elements , certain vitamins etc.) due to which it gave better results as compared to other nitrogen sources.

\section{Carbon: nitrogen ratio}

The results revealed that maximum biomass protein was formed when carbon: nitrogen was $2.4 \mathrm{~g} \mathrm{~N} / \mathrm{L}$ as compare to other ratios. Similar observations have been observed by Mehmood et al.[6] who reported higher production of microbial biomass protein by fermentation of rice straw with Arachniotus sp.

$$
\mathrm{pH}
$$

The results revealed that maximum biomass yield and biomass protein $(4.75 \mathrm{~g} / \mathrm{L})$ was obtained with $\mathrm{pH}-4.0$. The results of the present study are in line with those of Sana [7] who produced biomass protein by corn stover with Arachniotus sp.

\section{Incubation period}

The results revealed that the maximum biomass true protein (6.09) and cell mass was obtained with 72-hour of incubation. The results are in line with that of Esabi [8] who produced single cell protein from Ram Horn Hydrolysate.

\section{Large scale production of biomass}

After optimizing various conditions (substrate: water ratio, carbon : nitrogen ratio, nitrogen source, optimum $\mathrm{pH}$ and incubation period) for the production of microbial biomass protein, large scale microbial biomass was produced using fermentor of 20-liters capacity with 100percent oxygen provision with rpm (120). Dried biomass, obtained after fermentation, was subjected to analysis for crude protein , true protein, crude fiber, ether extract, ash, NFE, calorific value, RNA contents and minerals ( calcium, sodium, phosphorus and chloride) using standard methods.

Biological evaluation

Average gain in body weight, feed consumption, feed efficiency (FE), feed conversion ratio (FCR), protein efficiency ratio (PER) and net protein utilization (NPU) for standard and test rations have been summarized in Table 1.
Table 1 Average Weight Gain, Feed Consumption, Feed EfFiciency, PROTEIN EFFICIENCY RATIO, FEED EFFICIENCY,FEED CONVERSION RATIO, PROTEIN EFFICIENCY RATIO AND NET PROTEIN UTILIZATION FOR STANDARD AND TEST DIET

\begin{tabular}{lclllc}
\multicolumn{5}{c}{ Rations } & \\
Description & A & B & C & SE \\
& & & & \\
\hline Weight gain per chick.(g/d) & 207.6 & 225.8 & 230.8 & 15.21 \\
Feed consumption (g/d) & 475.2 & 501.2 & 521.2 & 25.11 \\
Feed efficiency & 0.44 & 0.45 & 0.44 & 0.15 \\
Feed conversion ratio & $2.28 \mathrm{~b}$ & $2.22 \mathrm{ab}$ & $2.32 \mathrm{a}$ & 0.12 \\
Protein efficiency ratio & 1.89 & 1.95 & 1.92 & 0.54 \\
Net protein utilization & $38.72 \mathrm{a}$ & $37.27 \mathrm{a}$ & $34.14 \mathrm{~b}$ & 0.75 \\
& & & &
\end{tabular}

Weight gain

The highest weight gain was recorded in the chicks fed on ration containing 60 percent replacement of biomass protein with soybean meal (C) followed in descending order by those fed on ration 30 percent replacement of biomass protein with soybean meal (B) and control ration (A). It indicated that microbial biomass protein can be partially replaced by soybean meal in the rations of broiler chicks without having any detrimental effects on weight gain of birds. The results of the present study are in line with that of Joshi et al [9] who produced animal feed from apple pomace on large scale by solid state fermentation with five yeasts (Saccharomyces cerevisiae. Candida utilis. Torula utilis. Schizosaccharomyces pombe and Kloeckera spp). Fermented apple pomace mixed with a standard broiler feed (1:1 ratio) was comparable to the standard feed. The broilers gained weight regularly upto 8 weeks and no mortality/abnormality was observed.

\section{Feed consumption}

The lowest feed consumption was recorded on standard ration (A). Maximum fed was consumed by chicks fed on ration $(\mathrm{C})$ in which 60 percent of the soybean protein was replaced with microbial biomass. The results of the present study is also in line with that of Ikram-ul-Haq [10] who produced single cell protein from Brevibacterium flavum and Arachniotus sp. while the substrate used for the microbial protein production was rice polishing. He replaced this microbial protein with that of Fish meal.

\section{Feed efficiency(gain/feed)}

The data on feed efficiency of chicks ration A showed better efficiency as compared to other two experimental rations. Analysis of variance of feed efficiency shows non-significant differences. It shows that soybean meal may be replaced successfully upto 60percent with microbial protein of Aspergillus terreus. The results of the present study are in line with Khan et.al [11] who had observed that feed efficiency was not affected by the dietary yeast biomass. Similar results were also found by Safdar [12] who found non-significant differences in feed efficiency of two experimental rations when up to 50 percent of the fish meal of the control diet was replaced by biomass protein in the diet of broiler chicks. The results of the present study are inagreement with that of Saima [5] who produced single cell protein from Candida utilis and Brevibacterium flavum using wheat bran as a substrate. Fish meal of the diet was replaced upto 50 percent with microbial biomass and non-significance 
results were recorded.

Feed conversion ratio (feed/gain)

Analysis of variance shows that non-significant difference among experimental rations. The results of the present study are in line with that of Chavez et.al [13] who reported non-significance differences among the standard and test diet when Chaetominum cellulolyticum biomass was fed to chicks.

\section{Protein efficiency ratio}

Analysis of variance revealed that PER differs non-significantly difference among various experimental diets. The results of the present study are in line with that of Khan et al. [11] who replaced 25 and 50 percent of the vegetable protein with microbial biomass produced from rice polishing with Candida utilis.

\section{Net protein utilization}

The findings of the present study are in line with that of Ikram-ul-haq [10] who produced microbial biomass protein from Brevibacterium flavum and Arachniotus sp. using rice polishing as a substrate. He replaced this biomass, 0, 25, 50, 75 and 100 percent with fish meal. The ANOVA of the variance shows significant difference among treatments.

\section{Growth kinetics}

In order to explain the trend of growth and efficiency of substrate utilization for the synthesis of protein by Aspergillus terreus, the growth kinetics was worked out. Various parameters were calculated for cell mass and protein production and also for amylases production (amylase and glucoamylase) (Table-2). The grams of product formed per gram of substrate utilized for fungi is usually reported as 0.5 $+0.05[14,15]$. Yogo et al. [16] however showed different values because of the reason that the substrate they used contained less quality of carbon required for protein synthesis. The rate of product formation $(\mathrm{Yx} / \mathrm{s})$ was found to be 0.553 which is closely related with that of Ather et.al [15] who reported 0.614.The product coefficient (Yp/s) observed during the present study was 0.344 which is closely related to that of Varavinit et.al. [17] who reported $\mathrm{Yp} / \mathrm{s}$ value as $0.4 \mathrm{gg}-1$

TABLE 2 VARIOUS GROWTH KinETICS PARAMETERS (CELl MASS AND Protein Formation, AMYLASES PRODUCTION) OF ASPERgILluS TERREUS.

\begin{tabular}{|c|c|c|}
\hline \multicolumn{2}{|c|}{ Parameters } & Aspergillus terreus \\
\hline \\
\hline $\mathrm{Yx} / \mathrm{s}$ & \multicolumn{2}{|c|}{0.553 gram cell mass /gram substrate utilized } \\
\hline $\mathrm{Yp} / \mathrm{s}$ & \multicolumn{2}{|r|}{0.344 gram protein /gram substrate utilized } \\
\hline $\mathrm{Yp} / \mathrm{x}$ & \multicolumn{2}{|c|}{0.622 gram protein /gram cell mass formation } \\
\hline YGAM/s & \multicolumn{2}{|r|}{ 1487.5 IU/gram of substrate utilized } \\
\hline YGAM/x & \multicolumn{2}{|r|}{ 2689.80 IU/ gram cell mass formation } \\
\hline YAMY/s & \multicolumn{2}{|r|}{ 937.50 IU/ gram substrate utilized } \\
\hline YAMY/x & \multicolumn{2}{|r|}{ 1695.30 IU/ gram cell mass formation } \\
\hline QGAM & \multicolumn{2}{|c|}{2060 volumetric glucoamylase formation rate } \\
\hline QAMY & \multicolumn{2}{|r|}{3038 volumetric amylase formation rate } \\
\hline Qp & \multicolumn{2}{|r|}{1.212 volumetric protein formation rate } \\
\hline Qx & \multicolumn{2}{|c|}{1.445 volumetric cell mass formation rate } \\
\hline \multirow[t]{3}{*}{$\mathrm{qp}$} & \multicolumn{2}{|r|}{0.2805 gram protein /gram cell mass $/ \mathrm{h}$} \\
\hline & & $1213.09 \mathrm{IU} /$ gram cell mass $/ \mathrm{h}$ \\
\hline & & $164.58 \mathrm{IU} /$ gram cell mass / $\mathrm{h}$ \\
\hline
\end{tabular}

\section{CONCLUSIONS}

The study findings suggested that microbial biomass produced (single cell protein) by Aspergillus terreus can be replaced upto $30 \%$ of the protein supply by soybean meal without any deleterious effects on growing broiler chicks.

\section{REFERENCES}

[1] B. B. Khan, A. Iqbal, and M. I. Mustafa. Sheep and goat production. TM Graphics, Al-Rehman plaza, St. \# 6, Munshi Mohallah, Aminpur Bazar, Faisalabad. 232-233, 2003.

[2] K.S. Bilgrami, and A. K. Pandey. Introduction to Biotechnology. First Edition, CBS Publishers and Distributors, Delhi-110032(India).pp-159-160, 1992.

[3] K. S. Siddiqui, M. J. Azar, M. H. Rashid, and M.I. Rajoka. Purification and the effect of $\mathrm{Mn++}$ on the activity of carboxymethyle cellulose from Aspergillus niger and Cellulomonas biazotea. Folia Microbiol.1996, 42 (4) : 303-311.

[4] R. G. D. Steel, and J. H. Torrie. Principles and Procedures of Statistics. A Biometrical Approach (2nd Ed.) McGraw Hill Book Co. Inc., New York, 1984.

[5] Saima. Bioconversion of wheat bran to biomass protein, its biological evaluation and detoxification of aflatoxin in broiler chicks. M.Sc. Thesis , Deptt. of Animal Nutrition , University of Agriculture , Faisalabad, 1996.

[6] Z. Mahmood, A. S. Hashmi, and M. Akthar. Isolation of mycotoxins produced by an antagonistic fungal organism, Arachniotus species. Pak. J. Agri. Sci.1990, 27 (4) : 314- 316.

[7] A. Sana, M. Rashid, M. Asghar and M.Yaqub. A study of optimum condition for the production of biomass protein from maize Stover by Arachniotus sp. Pak. J. Biol.Sci.1998, 1 (2) : 78 - 80, 1998.

[8] B. Esabi. Production of single cell protein from ram horn hydrolysate. Turk.J.Biol. pp:371-377, 2001.

[9] V. K. Joshi, K. Gupta, A. Devrajan, B.B. Lal, and S.P. Arya. 2000. Production and evaluation of fermented apple pomace in the feed of broilers. J food Sci. Technol. 2000, 37 (6): 609-612.

[10] Ikram-ul-Haq. Protein enrichment of rice polishing through metabiosis and its biological evaluation.Ph.D.Thesis. Deptt. of Animal Nutrition, University of Agriculture, Faisalabad, Pakistan, 2000.

[11] S. H. Khan, A. S. Hashmi, Z.A.Khan and A.H.Gilani. Bioconversion of defatted tice polishing to protein concentrate and its chemical and biological evaluation. Paper presented at All Pakistan Science Conference, Aitchison college, Lahore, 1993.

[12] M. Safdar. Production of biomass protein from beet pulp on pilot scale through metabiosis and its biological evaluation on broiler chicks. M.Sc. Thesis, Deptt. of Animal Nutrition .University of Agriculture , Faisalabad, 1995.

[13] E. R. Chavez, S.P. Touchburn, and M. Moo-Young. Microbial biomass protein from the fungus Chaetomimum cellulolyticum. Nutritive value for chicks and piglets. Anim. Feed Sci. and Technol.1988, 22:23-32.

[14] A. Rieche, W. Nordheim, A.Martini, and G. Muller. Total processing of potatoes in production of high quality feed with Candida utilis.Ztschr.Tierphysiol.Tierernahrung Futtermittelk.1966, 21: 144 153.

[15] M. Ather, A. S. Hashmi, A. H. Galani, N .Ahmed and K. H. Malik. Bioconversion of beet pulp into microbial biomass in feed batch culture and its biological evaluation in broiler chicks .Proceedings ,Second National Seminar on Nature Farming, University of Agriculture, Faisalabad ,Pakistan, 1995

[16] M. Yogo, Y. Miyable. and M.Tanaka.Yeast cells .Japan.Kokai.1976, $3 p p$.

[17] A. Varavinit, P. Srithongkum, C. De-Eknamkul, A.Assavanig. and K.Charoensiri. Production of single cell protein from cassava starch in air lift fermentor by Cephalosparium eichhorniae. Starch/Starrke.1996, 48(10): $379-382$. 